\title{
Initial Package Design Concepts Integrated Product Team (IPT) Summary Report
}

March 2000 


\section{Initial Package Design Concepts Integrated Product Team (IPT) Summary Report}

March 2000

\section{Idaho National Engineering and Environmental Laboratory} Idaho Falls, Idaho 83415

Prepared for the

U.S. Department of Energy

Under DOE Idaho Operations Office

Contract DE-AC07-99ID13727 


\section{EXECUTIVE SUMMARY}

Background: Initially, the question of transporting TRU waste to WIPP was raised as part of the EM Integration activities. The issue was re-examined as part of the system-wide view to re-engineer the TRU waste program. Consequently, the National Transportation Program and the National TRU Waste Program, in a cooperative effort, made a commitment to EM-20 to examine the feasibility of using rail to transport TRU waste material to WIPP. In December of 1999 Mr. Philip Altomare assembled a team of subject matter experts (SME) to define initial concepts for a Type B package capable of shipping TRU waste by rail (see Attachment 1 for a list of team members). This same team of experts also provided input to a preliminary study to determine if shipping TRU waste by rail could offer cost savings or other significant advantages over the current mode of operation using TRUPACT-II packages loaded on truck. As part of the analysis, the team also identified barriers to implementing rail shipments to WIPP and outlined a path forward. This report documents the findings of the study and its initial set of recommendations. As the study progressed, it was expanded to include new packages for truck as well as rail in recognition of the benefits of shipping large boxes and contaminated equipment.

Process: To accomplish the assigned tasks, the team planned and successfully executed two meetings wherein design assumptions, constraints, cost data, and waste source term data were analyzed in order to bound a package design, and then decide which factors would be included in a cost model that would allow comparison of various package designs. Source term data from the INEEL, as well as Savannah River, Hanford, and Rocky Flats were used, as these sites have the majority of the TRU waste, and also have a significant portion of their waste in boxes. Data from the EM Integration planning meeting held in Richland, Washington on 7 and 8 June 1999 concerning large container / oversize TRU waste was also used extensively. The team members from the INEEL met during the initial planning meetings, while team members from DOE HQ, Hanford, Savannah River Site, DOE-AL, Department of Transportation, and Rocky Flats were tied into subsequent facilitated meetings by telephone.

A simple cost model based upon a similar cost model used at Carlsbad was developed for use in running cost comparisons among the various design options proposed. Sensitivity analyses were also performed and used to determine which variables were most significant in the model. The results of these analyses were then tabulated, and are presented in the attachments and summarized below.

The evaluation performed by the team members is only qualitative at this point. The goal of this evaluation was to provide the team members an opportunity to subjectively evaluate the options and determine their plausibility, potential benefit, and identify barriers to implementing them.

Results: The study concluded that:

- Designing, developing, and fabricating a new Type B package for shipping TRU waste to WIPP by rail or truck conveyance appears to be technically and economically feasible and beneficial, and should be pursued in more detail

- It appears that the most attractive use of this concept is the possibility of moving boxed waste and large contaminated equipment, such as gloveboxes, without the expense of size reduction or repackaging the waste into drums or standard waste boxes. This advantage is based on the assumption that a characterization system can be developed that would enable the boxed waste to be characterized without opening the boxes

- A larger package shipped by rail could alleviate some size reduction issues

- There may be advantages in moving boxed waste or large objects between sites that have rail access. This could help some sites to meet closure agreements and possibly accelerate clean up and closure. While this may not prove more cost effective in moving the waste, it may save costs associated with site closures, such as building size reduction, repackaging, and characterization 
facilities, or closing facilities earlier

- Rail shipment of TRU waste has the most impact on those sites that have rail access and have significant volumes of TRU waste drums and boxes.

Implementation Barriers: The study identified the following barriers to be overcome:

- It is not clear at this time how difficult it would be to build and license a Type B package with a different design. This is particularly true in the case of a rectangular package that would likely have to pass severe full scale NRC testing because of the unfamiliar and novel rectangular design

- The ability to characterize TRU waste currently stored in boxes is in the development and testing phase. Current technology is inadequate to characterize the waste to the extent necessary to meet the requirements of the WIPP Waste Acceptance Criteria (WAC) and the WIPP Waste Acceptance Plan (WAP) issued as part of the RCRA Part B Permit

\section{Path Forward:}

- The preliminary study indicates that more detailed analysis is warranted. The team recommends continuing the study. More careful analyses should be conducted in the areas of optimizing the new packages size, better cost estimates, the interaction of the model variables, determining how much oversized waste could be shipped in a larger container, and investigate some form of regulatory relief

- A more careful and detailed study should be made of the existing packages in the complex that could be used to ship TRU waste by rail. The INEEL Spent Nuclear Fuel program is currently designing and certifying a package that is similar in size to two of the options that this team has recommended for further study

- Significant cost savings could be realized if TRU waste could be shipped as Low Specific Activity (LSA) waste meeting the requirements set forth for this waste by the Department of Transportation's Hazardous Materials Regulations. The merits of shipping TRU waste as LSA have been documented in the National Transportation Program report titled "Applicability of Low Specific Activity (LSA) Shipping Provisions to TRU Waste.” The National TRU Waste Program, in conjunction with the National Transportation Program, should pursue implementation of shipping material as LSA.

- The benefits of pursuing the design of a vented package should be explored, considering the fact that there is precedent based upon the current stance of the International Atomic Energy Association allowing continuous venting, as well as practices in other countries. Further work should be done that would consider the costs and risks associated with seeking an exemption for vented packages

- Further work should include pursuing a vented package and shipping some waste as LSA. This would likely require changing the Land Withdrawal Act, which currently requires that all TRU waste must be shipped to WIPP in a Type B package licensed by the NRC. Amending the Land Withdrawal Act to allow shipment of TRU waste in a non-NRC certified package (i.e., a DOTauthorized LSA package) may make economic sense, and further work should be done which would consider the costs and risks associated with seeking the change. 


\section{Initial Package Design Concepts Integrated Product Team (IPT) Summary Report}

1.0 Introduction: This study, which focuses on alternative package design concepts for shipping TRU waste, is part of a larger study to examine the potential for rail and / or truck transport from DOE sites in the contiguous United States to the disposal site at the Waste Isolation Pilot Plant (WIPP) in Carlsbad, NM. Shipments of TRU waste are presently made from DOE sites to WIPP in NRC-certified, Type B packages for truck conveyance. Several previous studies (Reference: SEIS, WIPP-98-2282, WIPP Transportation Assessment, DOE/WIPP 98-2282) have concluded that there was no advantage to shipment by rail over truck when considering the radiological risks associated with both transportation modes and a comparison of transportation cost for each mode. However, the assumptions, cost data, and modeling methods are now being revisited to determine if those conclusions are still valid. As part of that effort, a preliminary analysis was conducted to determine the feasibility of shipping TRU waste to WIPP using a new package designed for rail or truck transport.

2.0 Description of the Issue: The basis of previous studies was to consider the TRUPACT-II as the waste-shipping package for both truck and rail. For completeness in the evaluation, alternative package concepts for TRU waste transport are considered to determine if there is a significant affect in the comparison of rail versus truck transport. Considering alternatives to the TRUPACT-II package is justified in that the potential exists for shipping large waste boxes or oversized contaminated equipment, thereby reducing worker radiation exposure that would otherwise be incurred due to size reduction and repackaging activities. Also, the cost of repackaging and size reduction of the waste is potentially eliminated or reduced, improving the economics of rail transport. Further, TRU waste shipments to WIPP are planned out to 2033, thus allowing time to implement a new package concept, provided it is shown to be beneficial. It should be noted that new packages would incur costs for development, testing, licensing, and manufacture, as well as for new or modified equipment and facilities for loading and unloading. In the process of the evaluation the team also decided to consider a new package for truck or rail transport for the same reasons as noted previously.

The evaluation to which this analysis is contributing is intended primarily to address the feasibility of using rail to ship TRU material to WIPP, and includes studying alternative packages in addition to the TRUPACT-II. These concepts would then be used in modeling scenarios to determine if sufficient reason exists to proceed with a more sophisticated analysis.

The approach to developing alternative package concepts considered the following:

- Requirements and constraints of truck or rail transport

- Requirements and constraints of the WIPP facility

- An examination of the parameters and economics affecting rail versus truck shipments

- Other potential compensating benefits a new shipping package might offer, such as eliminating the health risk and cost of repackaging large waste boxes or size reducing large pieces of equipment, and

- An examination of existing packages that potentially could be utilized (e.g., spent fuel casks).

The "preliminary" package concepts presented herein are derived using available information, simplifying assumptions, and bounding-type configurations. The analysis performed is only sufficient to determine whether there is cause to proceed with the effort and, if so, to scope the work to follow.

3.0 Package Concept Recommendations: Using previous analyses, fundamental constraints as noted in the attachments, and in consultations with DOE and contractor SME's, preliminary TRU 
waste package concepts for rail have been used in this analysis to ascertain feasibility, help focus the problem, and assist in setting up evaluation scenarios for the rail feasibility study.

Initial work in this effort considered packages primarily for rail that had rectangular cross-sections and which were considered to be more efficient in moving the TRU waste that is packaged in drums and especially in boxes. Since many DOE sites having TRU waste do not have direct access to rail, additional packages for use by truck to move larger boxes were added that could go directly to WIPP or to a rail loading facility. The initial work also indicated that the largest possible shipping packages, within constraints of the truck or rail conveyances, that could pass the permitting test, would be the most economical. Review by several members of the team raised concerns as to the cost of designing and licensing a package with a rectangular cross-section. The concern was the restrictive regulatory requirements, not the practicality of the design. Accordingly, packages with a cylindrical cross section were added for evaluation, although they are less efficient in payload capacity.

The data from these preliminary analyses are summarized in Attachments 2 and 3. The data indicate that:

- Designing, developing, and fabricating a new Type B package for shipping TRU waste to WIPP by rail or truck conveyance appears to be technically and economically feasible and beneficial, and should be pursued in more detail

- It appears that the most attractive use of this concept is the possibility of moving boxed waste without the expense of repackaging the waste into drums or standard waste boxes. This advantage is based on the assumption that a characterization system can be developed that would enable the boxed waste to be characterized without opening the boxes

- A larger package shipped by rail could alleviate some size reduction issues, that could in turn reduce facility costs at existing facilities, or eliminate the need to build new facilities

- There may be advantages in moving boxed waste or large objects between sites. This could help some sites to meet closure agreements and accelerate clean up and closure. While this may not prove more cost effective in moving the waste, it may save costs associated with site closures or meeting waste processing or removal agreements

- Rail shipment of TRU waste has the most impact on those sites that have rail access and have significant volumes of TRU waste drums and boxes.

The shipping package concepts shown below are not optimized with respect to drums, boxes, or contaminated equipment that might be shipped. Waste package data has been collected and indicates that a package larger than the TRUPACT-II would be useful. However, the analysis is not sufficiently complete to allow selection of an optimum package(s). Approximate internal dimensions are given for each concept, taking into consideration the external structure that would be required to pass licensing tests (e.g., containment and drop tests). Some increase or decrease in dimensions would be expected in the design process to accommodate the specific types of waste packages to be shipped.

A total of eleven options for alternative packages were analyzed. Based upon the analyses conducted, the following package sizes appear to be attractive and warrant a more detailed analysis. The packages are listed here by the team in order of preference, and should be pursued in this order if the development effort proceeds:

Concept 1: A cylindrical package with internal dimensions of six feet in diameter and 15 feet in length.

Discussion: This concept is a longer version of the TRUPACT-II but would hold two $4 \times 4 \times 7$ - foot boxes or four stacks of seven drums ( 28 total drums). Two packages could be loaded on a truck, or three per rail car. This longer version of the TRUPACT-II for truck is also competitive with the TRUPACT-II for truck, but is not as competitive for rail 
shipments. The package could hold two $4 \times 4 \times 7$-foot waste boxes, which is an added benefit. The longer length, however, is considered more difficult to pass the NRC Type $\mathrm{B}$ certification requirements. Extending the TRUPACT-II in this manner offers the advantage of using many of the same design features, such as closure methods, leak testing, etc.

Package Concerns: This package may not be as simple as just extending the current TRUPACT-II. A more robust design may be necessary to handle the increased weight. Loading and unloading drums into the package may be difficult. Boxed waste would likely require a removable "basket" for fitting rectangular boxes into a cylinder.

Concept 2: A cylindrical package with internal dimensions of 7.5 feet in diameter and 22 feet in length.

Discussion: Similar to Concept 1 for rail, but this concept is wider and longer to provide for three $5 \times 5 \times 7$-foot boxes, three $4 \times 4 \times 7$-foot boxes, or six stacks of eight drums (48 total drums). This package is competitive with the TRUPACT-II for drums, and also could potentially ship up to $96 \%$ of the existing waste boxes. A spent nuclear fuel Type B cask for rail of similar dimensions is presently being designed at INEEL that would indicate that this is not an unreasonable concept.

Package Concerns: The implementation of this concept would potentially take longer and cost more than making changes to the TRUPACT-II as in Concept 1 due to its increased size. Loading and unloading drums into the package may be difficult. Boxed waste would likely require a removable "basket" for fitting rectangular boxes into a cylindrical package.

Concept 3: A cylindrical package with internal dimensions of six feet in diameter and eight feet in length.

Discussion: Like Concept 1, this package is essentially a length extension of the presently used TRUPACT-II that could accommodate the frequently used $4 \times 4 \times 7$-foot TRU waste box. It could be used for truck or rail but would be shipped lying on the side because of the extra length. The package would hold one $4 \times 4 \times 7$-foot box or two stacks of seven 55-gallon drums (14 total drums). Two or three packages could be loaded on a truck or five per rail car. This package appears competitive with the present TRUPACTII for truck shipment. Extending the TRUPACT-II in this manner also offers the advantage of using many of the same design features, such as closure methods, leak testing, etc. The ability to handle a large waste box has the potential for considerable cost savings.

Package Concerns: As before, this package may not be as simple as just extending the current TRUPACT-II. A more robust design may be necessary to handle the increased weight. Loading and unloading drums into the package may be difficult. Boxed waste would likely require a removable "basket" for fitting rectangular boxes into a cylinder.

Concept 4: A rectangular package with internal dimensions of 8 feet by 8 feet by 20 feet.

Discussion: This version for rail shipments that would hold up to ten $4 \times 4 \times 7$-foot boxes, or four $5 \times 5 \times 8$-foot boxes, or 80 drums. The concept is similar in many respects to the 
packages placed in an ATMX railcar and the original TRUPACT-I concept. The edges and corners are assumed rounded for structural integrity. A 55 gallon drum loading three wide, stacked two high and 12 deep, or 72 drums, similar to an ATMX with a twopackage loading of 144 drums, is assumed. It is assumed that two packages could be carried in an enclosed railcar. If certifiable, this package would be competitive with TRUPACT-II's on trucks and could hold a substantial number of boxes. Although NRC certification under present regulations may be difficult, the potential for this package, which is similar to the ATMX in dimensions, is worthy of further consideration.

Package Concerns: The option is attractive, but it has drawbacks. It is questionable whether this package could survive a drop test, but with creative design of the package, extra protection afforded by an ATMX type railcar, and consideration of the type of waste being transported, exemptions might be possible. It would likely require an amendment to the Land Withdrawal Act, but it could be designed to meet current DOT requirements. NRC certification of this package is considered difficult. While the rectangular shape was not considered impossible to certify, the general opinion of package designers was that it would be difficult.

Concept 5: A rectangular package with internal dimensions of six ft. by six ft. by eight $\mathrm{ft}$.

Discussion: This concept is a rectangular cross-section package for truck (approaching the largest width) or rail that provides for larger box payloads. One $4 \times 4 \times 7$-foot or one $5 \times 5 \times 8$-foot box, or two stacks of nine drums (18 total drums) could be accommodated. Three packages could be placed on a truck or five on a railcar. The rectangular cross section is more efficient for packing drums or boxes and is competitive with the TRUPACT-II when used on a truck. It does not appear as cost effective for rail, but may still be beneficial to have to ship boxed waste by truck or rail.

Package Concerns: NRC certification of this package is considered difficult. While the rectangular shape was not considered impossible to certify, the general opinion of package designers was that it would be difficult.

The package concepts given above were derived considering the regulatory and physical constraints imposed by truck and rail transportation and WIPP disposal. These constraints and assumptions were also utilized to perform the economic feasibility analyses given in Attachments 2 and 3. To select a preferred final package design, a more thorough evaluation of the capabilities and constraints of the conveyances and transportation system will be required.

Also included in this report is a graphical depiction (Attachment 4) of an evaluation by the subject matter experts who participated in this analysis. This data does not indicate that the participants clearly preferred any option(s). This depiction was based on scoring by the SME's against the following criteria: cost, schedule, technical feasibility, risk considerations, and integration benefit. The graphic depiction is a summary of the scores provided. The scoring summary shows no clear preference for any of the options.

The available data, assumptions, and model results seem sufficiently reasonable to conclude that there is cause to continue the evaluation of new packages for transport of TRU waste from DOE sites to WIPP by rail. As a final recommendation, the team recommends that Concepts 1 through 5 be carried forward and evaluated in greater detail in the planned follow-on scenario analysis. 
4.0 Benefits of the Concepts: The team identified the following benefits to pursuing an alternative package design for TRU waste:

1. A major benefit of developing a new package and shipping TRU waste by rail or truck lies in the ability to ship a large portion of the boxed waste in the DOE complex "as-is" without size reduction or being repackaged. However, this concept is only inviting provided the boxed waste can be properly characterized to the requirements of the WIPP Waste Acceptance Criteria (WAC) and the WIPP Waste Acceptance Plan (WAP). This requires advances in the current capabilities of boxed waste characterization systems. This potentially offers large cost savings, and also reduces worker exposure. Assuming this is achievable, Table 1 below summarizes the boxed waste inventory and how much could possibly be shipped directly to WIPP. Table 2 provides estimates on costs that could be saved by shipping the boxes directly. Table 2 also indicates that savings associated with not repackaging the waste could make alternative packages more cost effective. The inventory displayed in these two tables was provided by the SME's from those sites that participated in the analysis

2. There may be advantages in moving boxed waste or large objects between sites. This could help some sites to meet closure agreements and possibly accelerate cleanup and closure. While this may not prove more cost effective in moving the waste, it may save costs associated with site closures or closing facilities earlier.

3. Another potential benefit is reduced costs associated with higher payload shipments for larger packages. Truck versus rail costs were calculated on a "per drum" and life-cycle basis for comparison using a modification of a model developed by Phil Gregory, WID, and further refined by Adam Rogers, INEEL. The model is a screening tool, and does not provide a thorough analysis. The model is not complex and is an excellent tool for a straightforward comparative analysis. Input parameters and cost results are given in Attachments 2 and 3. Attachment 2 shows the calculation results as the cost of moving a drum, while Attachment 3 shows the results expressed in total life cycle cost. While each analysis used somewhat different assumptions, the overall results were much the same. The results presented in these two attachments, along with other considerations such as repackaging and resizing, led the team to select the five alternative shipping package concepts for further consideration. 


\section{Table 1 - Boxed Waste Inventory Summary (See Note1)}

\begin{tabular}{|c|c|c|c|c|c|}
\hline Site & $\begin{array}{c}\text { Total Number } \\
\text { of Boxes } \\
\text { Containing } \\
\text { TRU Waste }\end{array}$ & $\begin{array}{c}\text { Number of } \\
\text { Boxes with } \\
\text { Dimensions less } \\
\text { than or equal to } \\
\mathbf{4 x 4 \times 7} \\
\text { (dimensions in } \\
\text { feet) }\end{array}$ & $\begin{array}{c}\text { Number of } \\
\text { Boxes with } \\
\text { Dimensions less } \\
\text { than or equal to } \\
5 \times 5 \times 8 \\
\text { (dimensions in } \\
\text { feet, see Note } 2 \text { ) }\end{array}$ & $\begin{array}{c}\text { Number of } \\
\text { Boxes with } \\
\text { Dimensions } \\
\text { greater than } \\
\mathbf{5 x 5 \times 8} \\
\text { (dimensions in } \\
\text { feet, see Note 3) } \\
\end{array}$ & $\begin{array}{c}\text { Boxes Listed } \\
\text { Without } \\
\text { Dimensions }\end{array}$ \\
\hline Hanford & 729 & $\begin{array}{c}176 \\
(24 \%)\end{array}$ & $\begin{array}{c}117 \\
(16 \%)\end{array}$ & $\begin{array}{c}332 \\
(46 \%)\end{array}$ & $\begin{array}{c}104 \\
(14 \%)\end{array}$ \\
\hline INEEL & 11,392 & $\begin{array}{l}10,688 \\
(94 \%)\end{array}$ & $\begin{array}{c}557 \\
(5 \%) \\
\end{array}$ & $\begin{array}{c}147 \\
(1 \%) \\
\end{array}$ & None \\
\hline LLNL & 31 & $\begin{array}{c}22 \\
(71 \%)\end{array}$ & $\begin{array}{c}9 \\
(29 \%) \\
\end{array}$ & None & None \\
\hline NTS & 58 & $\begin{array}{c}58 \\
(100 \%) \\
\end{array}$ & None & None & None \\
\hline $\begin{array}{l}\text { Savannah } \\
\text { River }\end{array}$ & 320 & $\begin{array}{c}162 \\
(51 \%)\end{array}$ & $\begin{array}{c}147 \\
(46 \%)\end{array}$ & $\begin{array}{c}10 \\
(3 \%)\end{array}$ & None \\
\hline Total & 12,530 & $\begin{array}{l}11,106 \\
(89 \%)\end{array}$ & $\begin{array}{c}830 \\
(7 \%)\end{array}$ & $\begin{array}{c}489 \\
(4 \%)\end{array}$ & $\begin{array}{c}104 \\
(1 \%)\end{array}$ \\
\hline
\end{tabular}

1. This data is from a limited response and does not include contaminated equipment / materials from D\&D that could be boxed

2. The totals for the $5 \times 5 \times 8$ case are not inclusive of the $4 \times 4 \times 7$ case. Most of these boxes are $5 \times 5 \times 7$ (dimensions in feet).

3. The totals for the boxes measuring greater than $5 \times 5 \times 8$ case are not inclusive of the $4 \times 4 \times 7$ case and the $5 \times 5 \times 8$ case (dimensions in feet) 


\section{Table 2 - Cost of Repackaging Boxed TRU Waste}

\begin{tabular}{|c|c|c|c|c|c|c|}
\hline \multirow{2}{*}{$\begin{array}{c}\text { Box } \\
\text { Dimensions } \\
\text { (In Feet) }\end{array}$} & \multirow{2}{*}{$\begin{array}{c}\text { Box } \\
\text { Volume } \\
\text { (In cubic } \\
\text { meters) }\end{array}$} & \multirow[t]{2}{*}{$\begin{array}{l}\text { Total } \\
\text { Boxes }\end{array}$} & \multicolumn{2}{|c|}{$\begin{array}{l}\text { Repackaging Costs For All } \\
\text { Sites (See Note 1) }\end{array}$} & \multicolumn{2}{|c|}{$\begin{array}{c}\text { Repackaging Costs With } \\
\text { INEEL Excluded (See Note 1) }\end{array}$} \\
\hline & & & $\begin{array}{c}\text { \$ 4,500 per Drum } \\
\text { Equivalent } \\
\text { (See Note } 2)\end{array}$ & $\begin{array}{l}\text { \$4,180 per } \\
\text { cubic meter } \\
\text { (See Note } 3 \text { ) }\end{array}$ & $\begin{array}{c}\text { \$ 4,500 per Drum } \\
\text { Equivalent } \\
\text { (See Note } 2)\end{array}$ & $\begin{array}{l}\$ 4,180 \text { per } \\
\text { cubic meter } \\
\text { (See Note } 3 \text { ) }\end{array}$ \\
\hline $4 \times 4 \times 7$ & 3.17 & 11,106 & \$ 762 Million & $\$ 150$ Million & \$29 Million & \$ 5.5 Million \\
\hline $5 \times 5 \times 8$ & 5.66 & 830 & \$102 Million & $\$ 20$ Million & \$33 Million & $\$ 6.5$ million \\
\hline $\begin{array}{c}\text { Greater } \\
\text { than } 5 \times 5 \times \\
8\end{array}$ & $\begin{array}{c}\text { Not } \\
\text { Calculate } \\
\text { d }\end{array}$ & 489 & & & & \\
\hline $\begin{array}{c}\text { Boxes } \\
\text { Without } \\
\text { Dimensions }\end{array}$ & $\begin{array}{c}\text { Not } \\
\text { Calculate } \\
\text { d }\end{array}$ & 104 & & & & \\
\hline \multicolumn{3}{|c|}{ Total (See Note 4) } & \$ 864 Million & $\begin{array}{l}\$ 170 \\
\text { Million }\end{array}$ & \$ 62 Million & \$12 Million \\
\hline
\end{tabular}

1. Does not include facilities / capital costs.

2. Cost information taken from "CH-TRU Waste Packaging Optimization Report," Revision 1, December 1995, and provided by Mr. Don Pound, INEEL, January 2000.

3. Cost information from Contract No. DE - AC07-971D13481, Pg. 2, Unit Price Schedule for the Advanced Mixed Waste Treatment Facility at the INEEL.

4. Does not include costs for boxes greater than $5 \times 5 \times 8$ feet.

\subsection{Affected Sites:}

- Hanford

- INEEL

- LLNL

- NTS

- Savannah River

- Others (e.g., West Valley)

\subsection{Barriers to Implementation:}

1. It is not clear at this time how difficult it would be to build and license a Type B package with a different or novel design. This is particularly true in the case of a rectangular package that would likely have to pass severe full-scale NRC testing because of the unfamiliar and novel rectangular design. This would be a significant factor particularly in the case of the drop test. In order to distribute adequately the stresses encountered during full-scale testing of a conceptual rectangular package, the edges and corners will probably have to be rounded. This design constraint may negate any advantage of using the increased volume and cooperative shape of a rectangular package, and the ability to load or stack boxes. However, when considering the large volume of boxed waste, the potential program cost savings which appear to be quite large, and the added advantage of shipping TRU waste without repackaging or size reduction, it is worthwhile to 
pursue this concept. A precedent for a rectangular package does exist. The British have licensed a rectangular Type B cask ("Magnox flask") and tested it to requirements similar to those of the NRC. Current estimates for designing and certifying a Type B cask are from three to five years.

2. The ability to characterize TRU waste currently stored in boxes of various sizes (see Tables 1 and 2) does not exist. Current technology is inadequate to characterize the waste to the extent necessary to meet the requirements of the WIPP Waste Acceptance Criteria (WAC) and the WIPP Waste Acceptance Plan (WAP). However, the Mixed Waste Focus Area is currently pursuing technology development efforts in this arena, and plans to make available a boxed waste assay system capable of adequately characterizing a standard waste box $(3 \times 4 \times 6$-foot $)$, a $4 \times 4 \times 7$-foot box, and perhaps a $5 \times 5 \times 8$-foot box, in the next three to five years. Support for this program should be strengthened and it should receive the highest priority to ensure success, considering the favorable cost effect it could have.

3. Another related characterization issue is the fact that being able to ship more TRU waste by rail at a more rapid pace (intuitively) assumes that the waste can be characterized at a commensurate pace. Current experience does not support this assumption, meaning that the rate limiting steps in the process are not related to transportation assets, but are clearly related to waste characterization capabilities.

4. The inability to get good cost data from the railroads hampers comparative evaluations with trucks. Unless detailed and promising commitments are made to the railroad companies, they are reluctant to provide adequate and accurate cost data. Based on available data for the cost of shipping by truck (varying from $\$ 3.50$ to $\$ 9.00$ per truck mile), there may be considerable room for rate negotiations with the railroads.

5. Current wattage limits and weight limits restrict the number of drums that can be loaded into a TRUPACT-II. Currently, INEEL shipments are averaging only about 10 drums per shipment. Similar restraints may be present for a new larger rail package if regulatory relief is not obtained.

\subsection{Path Forward:}

- Consider a second phase to the study that focuses on further analytical studies of alternative package concepts. Match the shipment requirements to the specific design. In particular, the following items deserve much more detailed analysis:

- Refine the economic analysis begun here on the five design concepts to better define package and other costs

- Accurately calculate the costs to the major sites if it becomes necessary to repackage their existing waste into drums or the standard waste box, including facility costs. Then determine and compare the resultant cost differences

- The possibility of shipping waste without extensive size reduction (gloveboxes) which cannot be loaded into a drum or a standard waste box. With a larger rail package, some of the resizing efforts occurring in the complex may be reduced

- For the purposes of this analysis, the variables that affect cost of shipment were assumed to be independent of one another, which is likely not true. The interaction and interdependence of the various factors should be investigated

- Obtain better information concerning the structural capability of rectangular packages and longer cylindrical packages

- Determine if wattage limits or weight limitations could restrict package sizes. 
- A more careful and detailed study should be made of the existing packages in the complex that could be used to ship TRU waste by rail or truck. For example, there are a number of spent nuclear fuel Type B packages that are shipped by rail that may be useful. This concept offers the advantages of sharing development and production costs among programs, or avoiding entirely the cost of development by the TRU program. It also offers the opportunity to fill the pipeline to WIPP more rapidly. The INEEL Spent Nuclear Fuel program is currently designing and certifying a package that is similar in size to two of the options that this team has recommended for further study.

- Significant cost savings could be realized if TRU waste could be shipped as Low Specific Activity (LSA) waste meeting the requirements set forth for this waste in the Department of Transportation's Hazardous Materials Regulations. Current data indicate that a significant portion of the TRU waste in the complex inventory will assay as LSA, with estimates as high as 17\% (NTP report "Applicability of Low Specific Activity (LSA) Shipping Provisions to TRU Waste”). Current WIPP-relevant regulatory requirements and regulations prohibit this concept, but a strong case can be made to relax those requirements and agreements. The idea has merit due to significant cost savings, and should be pursued in the next phase of the study. An extensive test program may be necessary to convince regulators that the methodology is safe, and the waste must clearly be shown to be LSA.

- The benefits of pursuing the design of a vented package should be explored, considering the fact that there is precedent based upon the current stance of the International Atomic Energy Association allowing continuous venting, as well as practices in other countries. This eliminates the need for the restrictions on length of shipping time. Continuous venting is currently not permitted, and obtaining changes to this policy may be difficult. The NRC may not approve a vented package that cannot be readily controlled by the shipper, which could be the case with rail. Further work should be done which would consider the costs and risks associated with seeking an exemption.

- Pursuing a vented package and shipping some waste as LSA would require changing the Land Withdrawal Act. This act currently requires that all TRU waste must be shipped to WIPP in a package "the design of which has been certified by the Nuclear Regulatory Commission" (Land Withdrawal Act, Section 16.a.1). Amending the Land Withdrawal Act to allow shipment of TRU waste in a non-NRC certified package (i.e., a DOT authorized LSA package) may make economic sense, and further work should be done that would consider the costs and risks associated with seeking the change. 
Attachment 1 - Team Members

\begin{tabular}{|c|c|c|c|c|c|c|}
\hline NAME & $\begin{array}{l}\text { COMPANY / } \\
\text { SITE }\end{array}$ & PHONE & FAX & E-MAIL & FED-EX ADDRESS & MAIL ADDRESS \\
\hline $\begin{array}{l}\text { Altomare, } \\
\text { Phil }\end{array}$ & $\mathrm{DOE}-\mathrm{HQ}$ & $301-903-7476$ & $301-903-9770$ & philip.altomare@em.doe.gov & $\begin{array}{l}\text { US Department of Energy } \\
19901 \text { Germantown Road } \\
\text { Germantown, MD } 20874\end{array}$ & $\begin{array}{l}\text { US Department of Energy } \\
19901 \text { Germantown Road } \\
\text { Germantown, MD } 20874\end{array}$ \\
\hline Bhatt, Raj & BEWIIINEEL & $208-526-2773$ & $208-526-9555$ & bha@inel.gov & $\begin{array}{l}\text { B日Wl } \\
2525 \text { N. Fremont Ave. } \\
\text { Idaho Falls, ID } 83415- \\
4201\end{array}$ & $\begin{array}{l}\text { B日Wl } \\
\text { PO Box 1625, MS } 4201 \\
\text { Idaho Falls, ID } 83415- \\
4201\end{array}$ \\
\hline $\begin{array}{l}\text { Blackwell, } \\
\text { Kevin }\end{array}$ & FRA/DOT & $202-493-6315$ & & kevin.blackwell@fra.dot.gov & & \\
\hline $\begin{array}{l}\text { Daugherty, } \\
\text { Brent }\end{array}$ & BNFLISRS & $803-557-6304$ & $803-557-6306$ & brent.daugherty@srs.gov & \begin{tabular}{|l} 
BNFL \\
Bldg. 705-3C \\
P.O. Box 616 \\
Aiken, SC 29808
\end{tabular} & $\begin{array}{l}\text { BNFL } \\
\text { Bldg. 705-3C } \\
\text { P.o. Box 616 } \\
\text { Aiken, SC } 29808\end{array}$ \\
\hline $\begin{array}{l}\text { Fawcett, } \\
\text { Rick }\end{array}$ & B日WIIINEEL & $208-526-1284$ & $208-526-3857$ & fct@inel.gov & $\begin{array}{l}\text { B日Wl } \\
2525 \text { N. Fremont Ave. } \\
\text { Idaho Falls, ID } 83415\end{array}$ & $\begin{array}{l}\text { B日Wl } \\
\text { PO Box } 1625 \\
\text { Idaho Falls, ID } 83415\end{array}$ \\
\hline $\begin{array}{l}\text { Gregory, } \\
\text { Phil }\end{array}$ & WID /WIPP & $505-234-7469$ & $505-234-7056$ & $\begin{array}{c}\text { gregorp@wipp.carlsbad.nm. } \\
\text { us }\end{array}$ & $\begin{array}{l}\text { Westinghouse Electric Co. } \\
4021 \text { National Parks HWy. } \\
\text { GSA } 211 \\
\text { Carlsbad, NM } 88220\end{array}$ & $\begin{array}{l}\text { Westinghouse Electric } \\
\text { Co. } \\
\text { P.O. Box 2078, GSA } 211 \\
\text { Carlsbad, NM 88221- }\end{array}$ \\
\hline $\begin{array}{l}\text { Hamp, } \\
\text { Steven }\end{array}$ & DOE-AL / ALB & $505-845-5640$ & $505-845-5508$ & shamp@doeal.gov & $\begin{array}{l}\text { US Department of Energy } \\
\text { Pennsylvania and } \mathrm{H} \\
\text { Kirkland AFB } \\
\text { Albuquerque, NM } 87185\end{array}$ & $\begin{array}{l}\text { US Department of Energy } \\
\text { Albuquerque Operations } \\
\text { Office } \\
\text { P.O. Box } 5400\end{array}$ \\
\hline $\begin{array}{l}\text { Hladek, } \\
\text { Ken }\end{array}$ & $\begin{array}{c}\text { Waste Mgt. Fed. } \\
\text { Servicesi } \\
\text { Hanford }\end{array}$ & $509-372-3201$ & $509-376-1512$ & Ken_L_Hladek@rl.gov & $\begin{array}{l}\text { Waste Management } \\
\text { Hanford } \\
2440 \text { Stevens } \\
\text { Richland, WA } 99352\end{array}$ & $\begin{array}{l}\text { Waste Management } \\
\text { Hanford } \\
\text { P.O. Box } 700 \text { MSIN H6-30 } \\
\text { Richland, WA } 99352\end{array}$ \\
\hline $\begin{array}{l}\text { Holmes, } \\
\text { Frank }\end{array}$ & DOE-ID / INEEL & $208-526-3599$ & $208-526-7245$ & holmesfc@id.doe.gov & $\begin{array}{l}\text { US Department of Energy } \\
850 \text { Energy Place, MS } \\
1219 \\
\text { Idaho Falls, Idaho } 83415 \\
\end{array}$ & $\begin{array}{l}\text { US Department of Energy } \\
850 \text { Energy Place, MS } \\
1219 \\
\text { Idaho Falls, Idaho } 83415 \\
\end{array}$ \\
\hline
\end{tabular}




\begin{tabular}{|c|c|c|c|c|c|c|}
\hline $\begin{array}{l}\text { Keane, } \\
\text { Michael }\end{array}$ & $\begin{array}{l}\text { EM-76/DOE- } \\
\qquad \mathrm{HQ}\end{array}$ & $301-903-7275$ & $301-903-7613$ & michael.keane@em.doe.gov & $\begin{array}{l}\text { US Department of Energy } \\
\text { EM-76/1058/Cloverleaf } \\
20400 \text { Century Blwd. } \\
\text { Germantown, MD 20874 }\end{array}$ & $\begin{array}{l}\text { US Department of Energy } \\
\text { EM-76/1058/Cloverleaf } \\
20400 \text { Century Blwd. } \\
\text { Germantown, MD } 20874\end{array}$ \\
\hline $\begin{array}{l}\text { Kramer, } \\
\text { George }\end{array}$ & BEWIIINEEL & $208-526-0762$ & $208-526-1234$ & kramgl@inel.gov & $\begin{array}{l}\text { B日Wl } \\
2525 \text { N. Fremont Ave. } \\
\text { Idaho Falls, ID } 83415- \\
3405\end{array}$ & $\begin{array}{l}\text { B日Wl } \\
\text { PO Box } 1625 \\
\text { Idaho Falls, ID } 83415- \\
3405\end{array}$ \\
\hline $\begin{array}{l}\text { Lenarcic, } \\
\text { Ken }\end{array}$ & RMRS / RFETS & $303-966-2377$ & & kenneth.lenarcic@rfets.gov & $\begin{array}{l}\text { RFETSIRMRS } \\
\text { Highway 93, Bldg. } \\
\text { Golden, c0 80402-0464 }\end{array}$ & $\begin{array}{l}\text { RFETSIRMRS } \\
\text { P. O. Box } 464 \\
\text { Golden, CO 80402-0464 }\end{array}$ \\
\hline Luke, Dale & BEWIIINEEL & $208-526-3610$ & $208-526-1234$ & lukede@inel.gov & $\begin{array}{l}\text { B日Wl } \\
2525 \text { N. Fremont Ave. } \\
\text { Idaho Falls, ID } 83415- \\
3404\end{array}$ & $\begin{array}{l}\text { B日Wl } \\
\text { PO Box } 1625 \\
\text { Idaho Falls, ID } 83415- \\
3404\end{array}$ \\
\hline $\begin{array}{l}\text { McCall, } \\
\text { Dennis }\end{array}$ & $\begin{array}{c}\text { Waste Mgt. Fed. } \\
\text { Servicesi } \\
\text { Hanford }\end{array}$ & $509-376-1651$ & $509-376-0743$ & Dennis_L_McCall@rl.gov & $\begin{array}{l}\text { Waste Management } \\
\text { Federal Services } \\
345 \text { Hills } \\
\text { Richland, WA } 99352\end{array}$ & $\begin{array}{l}\text { Waste Management } \\
\text { Federal Services } \\
345 \text { Hills, H1-11 } \\
\text { Richland, WA } 99352\end{array}$ \\
\hline Moss, John & B日WIIINEEL & $208-526-2615$ & $208-526-1234$ & mossri@inel.gov & $\begin{array}{l}\text { B日Wl } \\
2525 \text { N. Fremont Ave. } \\
\text { Idaho Falls, ID } 83415- \\
3404\end{array}$ & $\begin{array}{l}\text { B日Wl } \\
\text { PO Box } 1625 \\
\text { Idaho Falls, ID } 83415 \text { - } \\
3404\end{array}$ \\
\hline $\begin{array}{l}\text { Portsmout } \\
\text { h, Jim }\end{array}$ & $\begin{array}{c}\text { Waste Mgt. / } \\
\text { Hanford }\end{array}$ & $509-376-7164$ & & $\begin{array}{c}\text { jim_portsmouth@smnsnw.c } \\
\text { om }\end{array}$ & & \\
\hline $\begin{array}{l}\text { Pound, } \\
\text { Don }\end{array}$ & B日WII INEEL & $208-526-8023$ & $208-526-9555$ & dxp@inel.gov & $\begin{array}{l}\text { B日Wl } \\
2525 \text { N. Fremont Awe. } \\
\text { Idaho Falls, ID } 83415- \\
4201\end{array}$ & $\begin{array}{l}\text { B日Wi-Idaho } \\
\text { P. O. Box 1625, MS-4201 } \\
\text { CFA 601, RWMC 637 } \\
\text { Idaho Falls, ID 83415- }\end{array}$ \\
\hline $\begin{array}{l}\text { Roesener, } \\
\text { Bob }\end{array}$ & B日WIIINEEL & $208-526-8388$ & $208-526-0425$ & rsq@inel.gov & $\begin{array}{l}\text { B日Wl } \\
2525 \text { N. Fremont Ave. } \\
\text { Idaho Falls, ID } 83415\end{array}$ & $\begin{array}{l}\text { B日Wl } \\
\text { PO Box } 1625 \\
\text { Idaho Falls, ID } 83415\end{array}$ \\
\hline $\begin{array}{l}\text { Rogers, } \\
\text { Adam }\end{array}$ & BEWIIINEEL & $208-526-3298$ & $208-526-1234$ & rogeaz@inel.gov & $\begin{array}{l}\text { B日Wl } \\
2525 \text { N. Fremont Ave. } \\
\text { Idaho Falls, ID } 83415\end{array}$ & $\begin{array}{l}\text { B日Wl } \\
\text { PO Box } 1625 \\
\text { Idaho Falls, ID } 83415\end{array}$ \\
\hline
\end{tabular}




\begin{tabular}{|c|c|c|c|c|c|c|}
\hline $\begin{array}{l}\text { Shariff, } \\
\text { Farok }\end{array}$ & WID / WIPP & 505-234-7376 & $505-234-7056$ & $\begin{array}{c}\text { shariff@wipp.carlsbad.nm.u } \\
\text { s }\end{array}$ & $\begin{array}{l}\text { Westinghouse Electric Co. } \\
4021 \text { National Parks Hwy., } \\
\text { GSA } 211 \\
\text { Carlsbad, NM } 88220\end{array}$ & $\begin{array}{l}\text { Westinghouse Electric } \\
\text { Co. } \\
\text { P.O. Box 2078, GSA } 211 \\
\text { Carlsbad, NM 88221- }\end{array}$ \\
\hline Wells, Jerry & DOE-ID /INEEL & $208-526-5296$ & 208-526-0160 & wellsjl@id.doe.gov & $\begin{array}{l}\text { US Department of Energy } \\
850 \text { Energy Place, MS } \\
1118 \\
\text { Idaho Falls, Idaho } 83415 \\
\end{array}$ & $\begin{array}{l}\text { US Department of Energy } \\
850 \text { Energy Place, MS } \\
1118 \\
\text { Idaho Falls, Idaho } 83415 \\
\end{array}$ \\
\hline $\begin{array}{l}\text { Williams, } \\
\text { Mona }\end{array}$ & DOE-AL / ALB & $505-845-5405$ & 505-845-5508 & mfwilliams@doeal.gov & $\begin{array}{l}\text { US Department of Energy } \\
\text { Pennsylwania and } \mathrm{H} \\
\text { Kirkland AFB } \\
\text { Albuquerque, NM } 87185 \\
\end{array}$ & $\begin{array}{l}\text { US Department of Energy } \\
\text { Albuquerque Operations } \\
\text { Office } \\
\text { P.O. Box } 5400\end{array}$ \\
\hline \multicolumn{7}{|l|}{$\mathrm{CC}:$} \\
\hline & & & & & & \\
\hline $\begin{array}{l}\text { Mustin, } \\
\text { Tracy }\end{array}$ & $\mathrm{DOE}-\mathrm{HQ}$ & $202-586-2676$ & & tracy.mustin@em.doe.gov & & \\
\hline $\begin{array}{l}\text { Smith, } \\
\text { Ralph }\end{array}$ & $\begin{array}{l}\text { DOE-CAO I } \\
\text { WIPP }\end{array}$ & $505-234-7335$ & & $\begin{array}{c}\text { smithr@wipp.carlsbad.nm.u } \\
\text { s }\end{array}$ & $\begin{array}{l}\text { US Department of Energy } \\
4021 \text { National Parks Hwy., } \\
\text { GSA } 223 \\
\text { Carlsbad, NM } 88220\end{array}$ & $\begin{array}{l}\text { US Department of Energy } \\
\text { P.O. Box } 3090, \text { GSA } 223 \\
\text { Carlsbad, NM } 88220\end{array}$ \\
\hline $\begin{array}{l}\text { Wade, } \\
\text { Lynne }\end{array}$ & DOE-HQ & $301-903-6828$ & $301-903-4307$ & lynnewade@em.doe.gov & $\begin{array}{l}\text { US Department of Energy } \\
19901 \text { Germantown Road } \\
\text { Trevion II } \\
\text { Germantown, MD } 20874\end{array}$ & $\begin{array}{l}\text { US Department of Energy } \\
19901 \text { Germantown Road } \\
\text { Trevion II } \\
\text { Germantown, MD } 20874 \\
\end{array}$ \\
\hline
\end{tabular}


Attachment 2 - Truck versus Rail Comparison by 55-gal Drum Cost for Alternative TRU WASTE Packages

\begin{tabular}{|c|c|c|c|c|c|c|c|c|c|c|c|c|}
\hline & $\begin{array}{c}\text { Truck } \\
\text { TRUPACT } \\
\text {-II }\end{array}$ & $\begin{array}{c}\text { Rail } \\
\text { TRUPACT } \\
\text {-II }\end{array}$ & $\begin{array}{c}\text { Truck } \\
\text { 6'diam } 8\end{array}$ & $\begin{array}{c}\text { Rail } \\
\text { 6'diam 8, }\end{array}$ & $\begin{array}{c}\text { Truck } \\
\text { 6'diam } 15\end{array}$ & $\begin{array}{c}\text { Rail } \\
\text { 6'diam 15, }\end{array}$ & $\begin{array}{c}\text { Rail } \\
7.5^{\circ} \text { diam } 15,\end{array}$ & $\begin{array}{c}\text { Rail } \\
\text { 7.5diam } 22,\end{array}$ & $\begin{array}{c}\text { Truck } \\
\text { 6'x6'x8 }\end{array}$ & $\begin{array}{c}\text { Rail } \\
\text { 6'x6'x8 }\end{array}$ & $\begin{array}{c}\text { Rail } \\
\text { 8'x8'x12, }\end{array}$ & $\begin{array}{c}\text { Rail } \\
8 \text { 'x8'x20, }\end{array}$ \\
\hline \multicolumn{13}{|l|}{ Per Drum Shinning } \\
\hline Rt miles (round trin) & 2800 & 2900 & 2800 & 2900 & 2800 & 2900 & 2900 & 2900 & 2800 & 2900 & 2900 & 2900 \\
\hline Packages ner truck/rail & 3 & 6 & 3 & 5 & 2 & 3 & 3 & 2 & 3 & 5 & 4 & 2 \\
\hline Drums ner nackage & 14 & 14 & 14 & 14 & 28 & 28 & 32. & 48 & 18 & 18 & 48 & 72. \\
\hline Ffficiencv \% & 85 & 85 & 85 & 85 & 85 & 85 & 85 & 85 & 85 & 85 & 85 & 85 \\
\hline Shinnino cost ner drum. & $\$ 280$ & $\$ 339$ & $\$ 280$ & $\$ 408$ & $\$ 209$ & $\$ 339$ & $\$ 297$ & $\$ 297$ & $\$ 161$ & $\$ 237$ & $\$ 148$ & $\$ 198$ \\
\hline \multicolumn{13}{|l|}{ Parkage Cost Rv Drum } \\
\hline Develon/Cert Cost $\$$ & 0 & 0 & $3 \mathrm{M}$ & $3 \mathrm{M}$ & $3 \mathrm{M}$ & $3 \mathrm{M}$ & $6 \mathrm{M}$ & $6 \mathrm{M}$ & $15 \mathrm{M}$ & $15 \mathrm{M}$ & $15 \mathrm{M}$ & $15 \mathrm{M}$ \\
\hline Package cost $\$$ & $335 \mathrm{~K}$ & $335 \mathrm{~K}$ & $500 \mathrm{~K}$ & $500 \mathrm{~K}$ & $500 \mathrm{~K}$ & $500 \mathrm{~K}$ & $500 \mathrm{~K}$ & $500 \mathrm{~K}$ & $750 \mathrm{~K}$ & $750 \mathrm{~K}$ & $750 \mathrm{~K}$ & $750 \mathrm{~K}$ \\
\hline Cucle time davs & 5 & 20 & 5 & 20 & 5 & 15 & 15 & 13 & 5 & 20 & 18 & 13 \\
\hline Package cost hu drum. & $\$ 80$ & $\$ 354$ & $\$ 139$ & $\$ 556$ & $\$ 70$ & $\$ 209$ & $\$ 207$ & $\$ 120$ & $\$ 160$ & $\$ 641$ & $\$ 289$ & $\$ 139$ \\
\hline Tntal enst hv drum. $\$$ & $\$ 360$ & $\$ 603$ & $\$ 419$ & $\$ 064$ & $\$ 278$ & $\$ 548$ & $\$ 505$ & $\$ 417$ & $\$ 321$ & $\$ 878$ & $\$ 437$ & $\$ 337$ \\
\hline$\%$ nackaoes in & $15 \%$ & $15 \%$ & $15 \%$ & $15 \%$ & $15 \%$ & $15 \%$ & $15 \%$ & $15 \%$ & $15 \%$ & $15 \%$ & $15 \%$ & $15 \%$ \\
\hline Numher of Packages & 17 & 73 & 17 & 67 & 8 & 25 & 22 & 12 & 10 & 39 & 17 & 8 \\
\hline Packagino Canital & $\$ 5.67 \mathrm{M}$ & $\$ 24.48 \mathrm{M}$ & $\$ 8.46 \mathrm{M}$ & $\$ 33.28 \mathrm{M}$ & $\$ 4.2$ & $\$ 12.46 \mathrm{M}$ & $\$ 10.92 \mathrm{M}$ & \$6.31 M & $\$ 7.28 \mathrm{M}$ & $\$ 29.04 \mathrm{M}$ & $\$ 13.08 \mathrm{M}$ & \$6.30 M \\
\hline
\end{tabular}

\begin{tabular}{|c|c|c|c|c|c|c|c|c|}
\hline \multirow[t]{2}{*}{ Assumption } & \multicolumn{3}{|c|}{ Quantity of TRU Waste } & \multicolumn{5}{|c|}{ Shipment Costs } \\
\hline & $\begin{array}{l}\text { Total Amount } \\
\text { Shipped } \\
\text { (Cubic meters / } \\
\text { life- cycle) }\end{array}$ & $\begin{array}{l}\text { Drum Equivalent } \\
\text { (drum / cubic meter) }\end{array}$ & $\begin{array}{l}\text { Volume Shipped per } \\
\text { Year (cubic meter / } \\
\text { year) }\end{array}$ & $\begin{array}{l}\text { Truck Shipment } \\
\text { Cost }(\$ / \text { mile })\end{array}$ & $\begin{array}{l}\text { Rail Shipment Cost (\$/ } \\
\text { shipment) }\end{array}$ & $\begin{array}{l}\text { Calculated Rail Cost (\$ / } \\
\text { mile per shipment) }\end{array}$ & $\begin{array}{l}\text { Railcars per } \\
\text { Shipment }\end{array}$ & $\begin{array}{l}\text { Calculated Rail Cost } \\
\text { (\$/ mile per railcar) }\end{array}$ \\
\hline Amount & 37,000 & 0.208 & 2,500 & $\$ 3.50$ & $\$ 72,558$ & $\$ 24.83$ & 3 & $\$ 8.34$ \\
\hline
\end{tabular}

\begin{tabular}{|l|l|l|l|l|l|l|l|}
\hline Assumption & \multicolumn{4}{|c|}{ Cycle Time } & \multicolumn{2}{c|}{ Route Length (Miles) } \\
\cline { 2 - 8 } & $\begin{array}{l}\text { Truck Transport } \\
\text { Speed } \\
\text { (miles / hour) }\end{array}$ & $\begin{array}{l}\text { Rail Transport } \\
\text { Speed } \\
\text { (miles / hour) }\end{array}$ & $\begin{array}{l}\text { Package } \\
\text { Load } \\
\text { Time } \\
\text { (Hours) }\end{array}$ & $\begin{array}{l}\text { Package } \\
\text { Unload } \\
\text { Time } \\
\text { (Hours) }\end{array}$ & $\begin{array}{l}\text { Number of 8 } \\
\text { Hour Shifts } \\
\text { per Day }\end{array}$ & $\begin{array}{l}\text { Truck } \\
\text { INEEL to WIPP } \\
\text { (Round trip) }\end{array}$ & $\begin{array}{l}\text { Rail } \\
\text { INEEL to WIPP } \\
\text { (Round trip) }\end{array}$ \\
\hline Amount & 45 & 15 & 8 & 4 & 2 & 2,800 & 2,900 \\
\hline
\end{tabular}

\begin{tabular}{|c|c|c|c|c|c|c|c|c|}
\hline \multirow[t]{2}{*}{ Assumption } & \multicolumn{3}{|c|}{ Package Development Cost (\$ / Package) } & \multicolumn{5}{|c|}{ Package Capital Cost (\$ / Package) } \\
\hline & $\begin{array}{c}\text { Modified TRUPACT } \\
\text { - II }\end{array}$ & Cylindrical & Rectangular & TRUPACT - II & Cylindrical & Rectangular & $\begin{array}{c}\text { Amortization Period } \\
\text { (Years) }\end{array}$ & $\begin{array}{l}\text { Percentage of } \\
\text { Packages in } \\
\text { Maintenance or in } \\
\text { Reserve }\end{array}$ \\
\hline Amount & $\$ 3,000,000$ & $\$ 6,000,000$ & $\$ 15,000,000$ & $\$ 335,000$ & $\$ 500,000$ & $\$ 750,000$ & 5 & $15 \%$ \\
\hline
\end{tabular}


Attachment 3. Alternatives Analysis Results

\begin{tabular}{|c|c|c|c|c|c|c|c|c|c|c|c|c|}
\hline & \begin{tabular}{|c|} 
Baseline \\
Truck \\
TRUPACT-II
\end{tabular} & \begin{tabular}{|c|} 
Option l- \\
Rail \\
TRUPACT-II
\end{tabular} & $\begin{array}{c}\text { Option 2- } \\
\text { Rail } \\
75^{\prime} \text { diax } \\
\text { 15' length }\end{array}$ & $\begin{array}{c}\text { Option 3- } \\
\text { Rail } \\
75^{\prime} \text { dia. } x \\
22 \text { ' length } \\
\\
\text { (Concept 2) }\end{array}$ & \begin{tabular}{|c} 
Option 4- \\
Truck \\
6' dia. $x$ \\
8' length \\
\\
\\
(Concept 3)
\end{tabular} & $\begin{array}{c}\text { Option 5- } \\
\text { Rail } \\
\text { 6' dia.x } \\
\text { 8' length }^{\prime} \\
\\
\text { (Concept 3) }\end{array}$ & $\begin{array}{c}\text { Option 6- } \\
\text { Truck } \\
6 \cdot \text { dia.x } \\
1^{\prime} \text { ' length } \\
\\
\text { (Concept } 1 \text { ) }\end{array}$ & $\begin{array}{c}\text { Option } 7- \\
\text { Rail } \\
6 ' \text { dia.x } \\
15 ' \text { length } \\
\\
\text { (Concept } 1 \text { ) }\end{array}$ & \begin{tabular}{|c|} 
Option 8- \\
Truck \\
6 'x6' $\times 8$ ' \\
\\
\\
(Concept 5)
\end{tabular} & $\begin{array}{c}\text { Option 9- } \\
\text { Rail } \\
\text { 6'x6'x8' } \\
\\
\text { (Concept 5) }\end{array}$ & \begin{tabular}{|c|} 
Option 10- \\
Rail \\
$8 ' x 8^{\prime} \times 12$
\end{tabular} & $\begin{array}{c}\text { Option 11- } \\
\text { Rail } \\
8^{\prime} \times 8^{\prime} \times 20 \\
\\
\\
\text { (Concept 4) }\end{array}$ \\
\hline \multicolumn{13}{|l|}{ INPUT } \\
\hline No. drums per package: & 14 & 14 & 32 & 48 & 14 & 14 & 28 & 28 & 18 & 18 & 48 & 72 \\
\hline No. pkgs per trailer (or railcar): & 3 & 6 & 3 & 2 & 2 & 5 & 2 & 3 & 2 & 5 & 4 & 2 \\
\hline Cubic meters per year shipped: & 6,115 & 6,115 & 6,115 & 6,115 & 6,115 & 6,115 & 6,115 & 6,115 & 6,115 & 6,115 & 6,115 & 6,115 \\
\hline \multicolumn{13}{|l|}{ OUTPUT } \\
\hline No. shipments per year: & 714.26 & 87.50 & 76.56 & 76.56 & 1071.39 & 105.00 & 535.70 & 87.50 & 833.31 & 81.66 & 38.28 & 51.04 \\
\hline No. years of shipments: & 6.05 & 6.05 & 6.05 & 6.05 & 6.05 & 6.05 & 6.05 & 6.05 & 6.05 & 6.05 & 6.05 & 6.05 \\
\hline Number of packages: & 50 & 207 & 91 & 61 & 50 & 207 & 25 & 104 & 39 & 161 & 61 & 41 \\
\hline Total transportation cost: & $\$ 42,353,480$ & $\$ 38,118,132$ & $\$ 33,353,365$ & $\$ 33,353,365$ & $\$ 63,530,220$ & $\$ 45,741,758$ & $\$ 31,765,110$ & $\$ 38,118,132$ & $\$ 49,412,393$ & $\$ 35,576,923$ & $\$ 16,676,683$ & $\$ 22,235,577$ \\
\hline Total Load/Unloading cost: (Not Used) & - & - & - & - & - & - & - & - & - & - & - & - \\
\hline Total maintenance cost: & $\$ 7,563,369$ & $\$ 31,312,347$ & $\$ 13,765,331$ & $\$ 9,227,310$ & $\$ 7,563,369$ & $\$ 31,312,347$ & $\$ 3,781,684$ & $\$ 15,731,807$ & $\$ 5,899,428$ & $\$ 24,354,047$ & $\$ 9,227,310$ & $\$ 6,201,962$ \\
\hline Package capital cost: & $\$ 16,750,000$ & $\$ 69,345,000$ & $\$ 51,500,000$ & $\$ 36,500,000$ & $\$ 28,000,000$ & $\$ 106,500,000$ & $\$ 15,500,000$ & $\$ 55,000,000$ & $\$ 44,250,000$ & $\$ 135,750,000$ & $\$ 60,750,000$ & $\$ 45,750,000$ \\
\hline Total System Cost: & $\$ 66,666,849$ & $\$ 138,775,479$ & $\$ 98,618,697$ & $\$ 79,080,675$ & $\$ 99,093,589$ & $\$ 183,554,105$ & $\$ 51,046,794$ & $\$ 108,849,939$ & $\$ 99,561,821$ & $\$ 195,680,971$ & $\$ 86,653,993$ & $\$ 74,187,539$ \\
\hline & & & & & & & & & & & & \\
\hline \multirow{2}{*}{\multicolumn{13}{|c|}{ Assumptions }} \\
\hline & & & & & & & & & & & & \\
\hline Assumption & $\begin{array}{c}\text { Total amount } \\
\text { shipped } \\
\left(\mathrm{m}^{3} / \mathrm{life}-\right. \\
\text { cycle) }\end{array}$ & $\begin{array}{c}\text { Drum } \\
\text { equivalent } \\
\left.\text { drum } / \mathrm{m}^{3}\right)\end{array}$ & $\begin{array}{c}\text { Volume } \\
\text { shipped per } \\
\text { year } \\
\left(\mathrm{m}^{3} / \text { year }\right)\end{array}$ & \begin{tabular}{|c|} 
Truck- \\
shipment cost \\
(\$/mile)
\end{tabular} & \begin{tabular}{|c|} 
Rail- \\
shipment \\
cost \\
(\$/shipment)
\end{tabular} & $\begin{array}{c}\text { Calculated } \\
\text { Rail cost } \\
\text { (\$/mile) } \\
\text { (per shipment) }\end{array}$ & $\begin{array}{c}\text { Railcars per } \\
\text { shipment }\end{array}$ & $\begin{array}{c}\text { Calculated rail } \\
\text { cost } \\
\text { (\$/mile) } \\
\text { (per railcar) }\end{array}$ & Truck & Rail & & \\
\hline Amount & 37,000 & 0.208 & 6,115 & 3.5 & 72,000 & 24.83 & 4 & 6.21 & 7 & 30 & & \\
\hline \multirow[t]{2}{*}{ Assumption } & \multicolumn{2}{|c|}{ Route Length (miles) } & \multicolumn{3}{|c|}{ Package Dvelopment Cost (\$package) } & \multicolumn{3}{|c|}{ Package Captial Cost (\$/package) } & & & & \\
\hline & \begin{tabular}{|c|} 
Truck \\
(ID to WIPF)
\end{tabular} & $\begin{array}{c}\text { Rail } \\
\text { (ID to WIPP) }\end{array}$ & \begin{tabular}{|c|} 
Modified \\
TRUPACT-II
\end{tabular} & Cylindrical & Rectangular & TRUPACT-II & Cylindrical & Rectangular & \begin{tabular}{|c|} 
Maintenance \\
cost per \\
package \\
(\$/year) \\
\end{tabular} & & & \\
\hline Amount & 2,800 & 2,900 & $3,000,000$ & $6,000,000$ & $15,000,000$ & 335,000 & 500,000 & 750,000 & 25,000 & & & \\
\hline
\end{tabular}




\section{Attachment 3 \\ (Continued) \\ Sensitivity Analysis}

Using a spreadsheet containing the Rail-to-WIPP model used in this study and an add-in software program called Crystal Ball, two output values (number of containers and total system cost) were evaluated to determine the sensitivity of five input variables:

- cycle time

- volume per year shipped

- rail cost per shipment,

- number of railcars per shipment, and

- lifetime total volume shipped.

Crystal Ball varies the input variables and varies them according to a Monte Carlo random number generator within user-defined boundaries. The input values are varied, the spreadsheet calculated, and the output values are stored. Once a predetermined number of runs are made, typically 1,000 to 10,000 , Crystal Ball then statistically calculates how the input variables impact the output. The advantage this program gives is an ability to define input variables having some degree of uncertainty, and then develop a robust model encompassing a desired outcome.

To define the input variables, Crystal Ball allows for many different probability distribution curves as defined by the modeler. For the Rail-to-WIPP model, the inputs were defined using a "most-likely" curve, a minimum value, a "most-likely" value, and a maximum value. This creates a triangular probability curve that Crystal Ball then uses to generate values using the Monte Carlo simulator. This input can be seen in the Assumption Figures below.

The two Sensitivity Charts show the results of this analysis. The impacts to the output variables (target forecast) are shown in these charts. The input variables are shown along the left side and are ranked by the relative impact on the output variable. The values are normalized from -1 to 1 . A positive correlation factor indicates that an input variable causes a positive change in the output variable. Conversely, a negative correlation factor indicates that a positive change in the input variable causes a negative change in the forecast value.

The first chart shows the sensitivity of Total System Cost to the five input variables. Cycle Time, Volume per Year Shipped, and Lifetime Total Shipped have the greatest consequence. This indicates the assumptions for each of these inputs should be very accurate in order to give a low degree of error in the Total System Cost. The chart presents a comparison among the five input variables, and indicates the relative sensitivity, or the relative impact on the Total System Cost. Once the degree of accuracy is high for the input variables, then another, more detailed analysis can be done to find out how much the input variable changes the output variable.

Similar conclusions can be made for the second Sensitivity Chart for Number of Containers as the output variable. Volume per Year Shipped and Cycle Time have the most impact. 

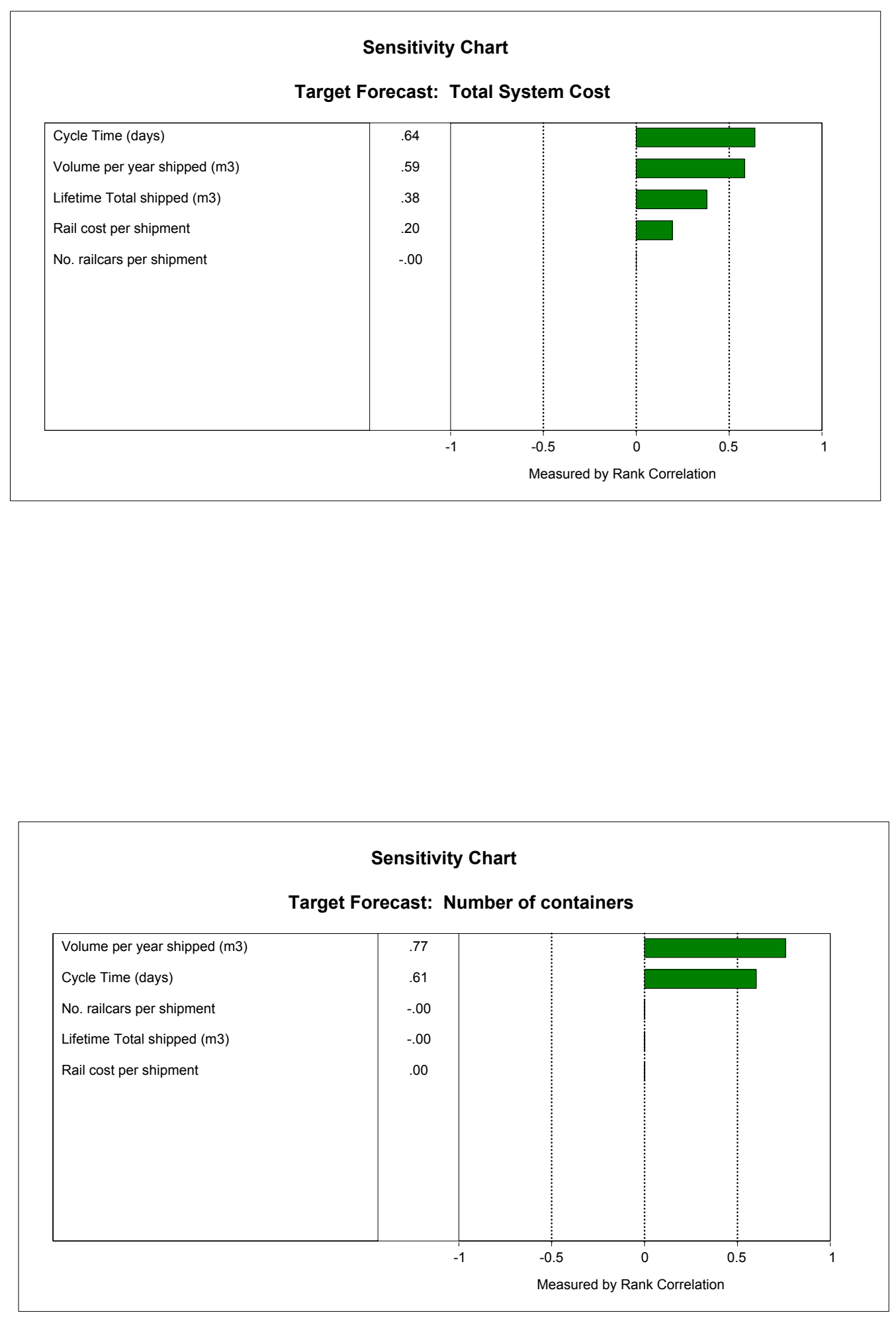
Tria ngula $r$ distrib utio $n$ w ith

Minim um

20.00

Like lie st

Ma xim um

Selected range is from 20.00 to

\section{Assumption: Volume peryearshipped}

Tria ng ula $\mathrm{r}$ d istrib ution w ith

Min im um

Like lie st

Maximum

Selected range is from 3,000 to

\section{Assumption: Ra il cost per shipment}

Tria ngula $\mathrm{r}$ distrib ution with

Minim um

$\$ 20,000$

Like lie st

Ma xim um

$\$ 75,000$

Selected range is from $\$ 20,000$ to

\section{Assumption: Life time Total shipped}

Tria ng u la $r$ distrib utio $n$ with Minim um

Like lie st

M a xim um

35,000

50,000

100,000

Selected range is from 35,000 to

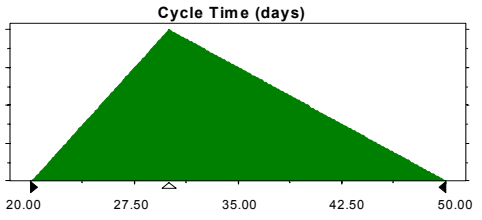

Cell: F17

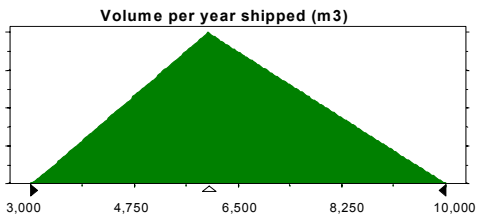

Cell: F24

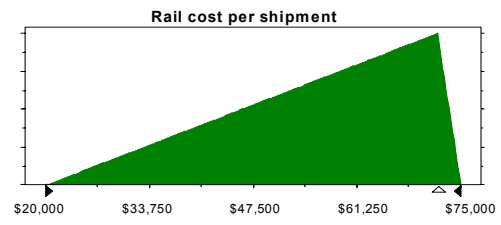

Cell: F3

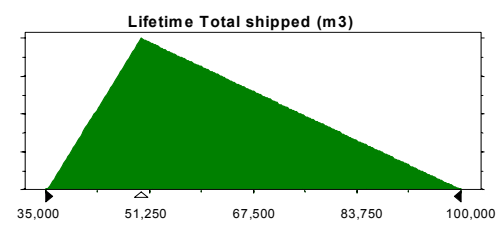

Cell: F7

2.00

4.00

8.00

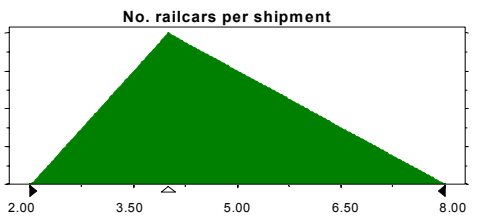




\section{Attachment 4}

\section{Consumer Report for Rail to WIPP Transportation}

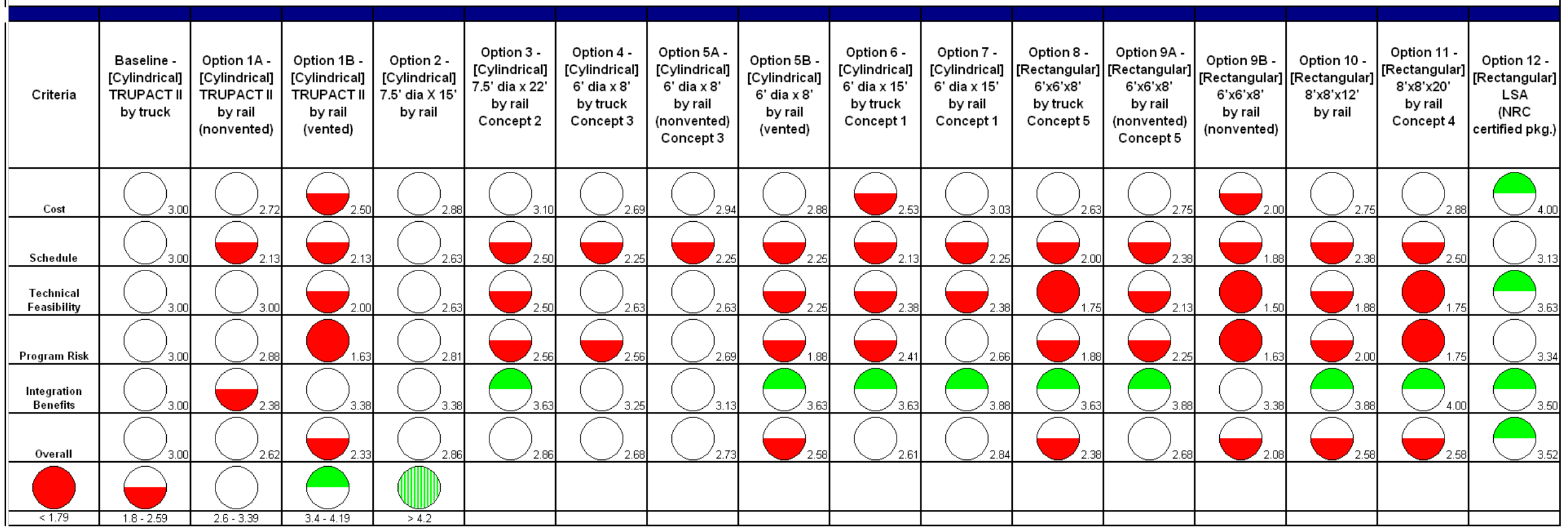

*This evaluation performed prior to calculations shown in Attachment 3, and is based on team member's perceptions 


\section{Attachment 4 \\ (Continued) \\ Team Scoring Summary Comments}

\section{The following comments were received concerning Option 1:}

The use would be similar to what already is in place with truck transport of TRUPACT-II. One of the disadvantages is the delay that would occur due to the additional number of TRUPACT-II's required to fill the rail car, the delays in turning the railcars / TRUPACT-II's around, and the time/costs to procure the additional TRUPACT-II's.

It is going to be a challenge to get NRC approval of a vented package. Even if it were a limited or periodic venting process, the NRC's concern would be how we could control that out on the rail during transit.

Continuous venting is not now permitted (10CFR71.443(h)), and it is not likely to change should a petition be submitted to ask to do so. Public comment would not be favorable to such a change.

On a per-unit basis, each option will be more expensive than building a TRUPACT-II.

For the existing TRUPACT-II shipped by rail, cost will be more because the fleet will have to be larger, and will require longer turnaround times. More units will be in lag storage awaiting rail transport, both loaded and unloaded.

This option is easily accomplished, not much benefit is realized.

\section{The following comments were received concerning Option 2:}

The implementation of Option 2 would take longer and cost more than making changes to the TRUPACT-II. The package would require design, qualification, and NRC approval. Following the approval of the package, the containers would have to be fabricated. The quantity of the containers and the tooling required to fabricate will also drive the schedule. On the positive side, the existing boxes should not be repackaged, and the shipping container could be designed to accommodate the majority of the boxed waste.

\section{The following comments were received concerning Option 3:}

The implementation of Option 2 would take longer and cost more than making changes to the TRUPACT-II. The package would require design, qualification, and NRC approval. Following the approval of the package, the containers would have to be fabricated. The quantity of the containers and the tooling required to fabricate will also drive the schedule. On the positive side, the existing boxes should not be repackaged, and the shipping container could be designed to accommodate the majority of the boxed waste. However, more boxes could be shipped at one time, but it might be a little harder to qualify through the testing process.

\section{The following comments were received concerning Option 4:}

The time and schedule to develop and implement this package would take longer and cost more than it 
would using the current TRUPACT-II. A lot of things could be taken from the TRUPACT-II design (closure methods, leak testing, impact limiters, and TRUCON) for implementation in the design. This design would be better than TRUPACT-II because it could handle the existing boxes without repackaging.

\section{The following comments were received concerning Option 5:}

The time and schedule to develop and implement this package would take longer and cost more than it would using the current TRUPACT-II. A lot of things could be taken from the TRUPACT-II design (closure methods, leak testing, impact limiters, and TRUCON) for implementation in the design. This design would be better than TRUPACT-II because it could handle the existing boxes without repackaging. This option would probably require more containers to maintain the shipping rate for the boxes due to the delays incurred while the rail car is being loaded with shipping packages. For the vented version, like Option 1, it seems like the NRC would be less likely to approve a package requiring venting that can not be readily controlled by the shipper.

\section{The following comments were received concerning Option 6:}

The time and schedule to develop and implement this package would take longer and cost more than it would using the current TRUPACT-II. A lot of things could be taken from the TRUPACT-II design (closure methods, leak testing, impact limiters, and TRUCON) for implementation in the design. Design and certification may be more difficult due to the extended design. This design would be better than TRUPACT-II because it could handle two of the existing boxes without repackaging.

\section{The following comments were received concerning Option 7:}

The time and schedule to develop and implement this package would take longer and cost more than it would using the current TRUPACT-II. A lot of things could be taken from the TRUPACT-II design (closure methods, leak testing, impact limiters, and TRUCON) for implementation in the design. This design would be better than TRUPACT-II because it could handle the existing boxes without repackaging.

This option would probably require more containers to maintain the shipping rate for the boxes due to the delays incurred while the rail car is being loaded with shipping packages. The extended design may be harder to qualify but can handle more boxes per shipment.

\section{The following comments were received concerning Option 8:}

Being a rectangular design, it is felt that the cost and schedule would take significantly more time to approve than the TRUPACT-II. Design review and modeling of other rectangular packages may have to be reviewed to minimize the amount of design efforts that would be required to certify the package. Due to the square corners, it would be less feasible to implement than the TRUPACT-II. The benefit would be better than TRUPACT-II since boxes would not be repackaged.

Non-circular designs would be contrary to the mindset of the regulators. It would take too much "robustness" to be engineered into a rectangular design such that its usefulness would be limited.

\section{The following comments were received concerning Option 9:}

Being a rectangular design, it is felt that the cost and schedule would take significantly more time to 
approve than the TRUPACT-II. Design review and modeling of other rectangular packages may have to be reviewed to minimize the amount of design efforts that would be required to certify the package. Due to the square corners, it would be less feasible to implement than the TRUPACT-II. The benefit would be better than TRUPACT-II since boxes would not be repackaged. Additional units would probably have to be procured in order to keep up with the shipping schedule due to the delays incurred at the facility to turn a rail car around. For the vented version, like Option 1, it seems like the NRC would be less likely to approve a package requiring venting that can not be readily controlled by the shipper.

\section{The following comments were received concerning Option 10:}

Being a rectangular design, it is felt that the cost and schedule would take significantly more time to approve than the TRUPACT-II. Design review and modeling of other rectangular packages may have to be reviewed to minimize the amount of design efforts that would be required to certify the package. Due to the square corners, it would be less feasible to implement than the TRUPACT-II. The benefit would be better than TRUPACT-II because it could handle two or three of the existing boxes without repackaging.

\section{The following comments were received concerning Option 11:}

Being a rectangular design, it is felt that the cost and schedule would take significantly more time to approve than the TRUPACT-II. Design review and modeling of other rectangular packages may have to be reviewed to minimize the amount of design efforts that would be required to certify the package. Due to the square corners, it would be less feasible to implement than the TRUPACT-II. The benefit would be better than TRUPACT-II because it could handle four or five of the existing boxes without repackaging.

\section{The following comments were received concerning Option 12:}

This option could be implemented into the program with a very large impact with regards to cost or schedule. It would require an amendment to the Land Withdrawal Act, but would be in compliance with DOT requirements. Since it is compliant, feasibility is not an issue. There would not be any program risk since it would be a current DOT approved method. The number of boxes per shipment would be dependent on the shipping method (truck or rail).

This option is attractive in its simplicity, but there are two problems. First is the requirement to ship to WIPP in NRC-certified packages, and second proving that the contents are in fact LSA. The NRC pulled its certifications on all its LSA packages effective 1 April 99. Maybe that would be justification to pursue a change to allow DOT "authorized" LSA packages. Proving the contents are LSA may be more problematic, i. e., the QC of how it is done.

Not required to have NRC license for LSA quantity. Change the Land Withdrawal Act.

Any rectangular design should be built on the outside in a round or oblong configuration but have a square configuration inside to accommodate boxes. Using this type of design should reduce overall design, testing, and certification costs. 


\section{Attachment 5 Assumptions Used}

\section{Shipping Package Assumptions:}

- Rectangular packages are rounded on edges and ends to withstand impact

- All alternative packages have impact limiters on the ends for protection

- Waste currently stored in boxes can be adequately characterized to the requirements of the WIPP WAC and WAP. This is considered reasonable for $4 \times 4 \times 7$-foot boxes, and possibly $5 \times 5 \times 8$-foot boxes, but becomes increasingly difficult for larger boxes and contaminated equipment. However, funded R\&D is in place

- Maintenance cost of package and carrier is $\$ 25,000$ per year (CH-TRU Waste Optimization Report, Rev. 1, 1995)

- The cost of repackaging a 55-gal drum equivalent is $\$ 4,500$ (CH-TRU Waste Optimization Report, Rev. 1, 1995, see Table 2 in the body of the report)

- The cost of designing and licensing a new package is \$6 million (assumption from CH-TRU Waste Optimization Report, Rev. 1, 1995)

Cycle Time Assumptions: A number of these assumptions were obtained from the WIPP Transportation Assessment Update, DOE/WIPP 98-2282, Chapter 4:

- Differences in cycle time are related to the time to load and unload packages, inspection of packages, plus travel time

- Maximum allowable transport time is 60 days according to the TRUPACT-II SARP. This estimates the worst case, with a safety factor for the hydrogen gas generation limit

- INEEL is used as the reference case

- Truck transport:

- $\quad$ The round trip distance from INEEL to WIPP is 2,800 miles

- $\quad$ Three TRUPACT-II's per truck carrying 14 drums per TRUPACT-II, however an $85 \%$ efficiency factor is used for drum loading

- $\quad$ Cost per mile is $\$ 3.50$

- Average travel speed is $45 \mathrm{mph}$

- $\quad$ Loading time is one crew shift per TRUPACT-II ( 8 hours)

- Unloading time is half of a shift per TRUPACT-II (4 hours)

- $\quad$ Loading cost per TRUPACT-II is $\$ 1,600$ (not used in this preliminary analysis)

- $\quad$ Unloading cost per TRUPACT-II is $\$ 800$ (not used in this preliminary analysis)

Considering the above factors, a cycle time of 7 days is assumed for the analysis in Attachment 3.

- Rail transport:

- $\quad$ The round trip distance from the INEEL to WIPP is 2,900 miles

- $\quad$ Rail transport configured as six TRUPACT-II's per railcar, carrying 14 drums per TRUPACT-II, however an $85 \%$ efficiency factor is used for drum loading

- Four rail cars constitute one shipment in the analysis presented in Attachment 3, while three railcars constitute a shipment in the analysis presented in Attachment 2 
- $\quad$ Cost per shipment is $\$ 72,559$ for a non-dedicated train from INEEL to WIPP 
- Cost per railcar, assuming 4 railcars per shipment is $\$ 6.25$ per railcar mile $(\$ 72,559$ / 4 railcars / 2900 miles), or $\$ 8.34$ per mile assuming 3 railcars per shipment

- Travel time is $15 \mathrm{mph}$ average (recalled as the average speed for the Three Mile Island rail shipments).

- Time to load one TRUPACT-II one crew for 8 hours. Preparation of waste packages for loading is not included

- $\quad$ Time to unload TRUPACT-II is roughly equivalent to half the time to load, or 4 hours per TRUPACT-II

- A two - shift operation is assumed with all package loading and unloading times roughly the same (TRUPACT-II's and new packages). The majority of the time is assumed to be inspecting and closing and sealing the packages

- Shipment from DOE site to WIPP could be accomplished from anywhere in U.S. in a maximum of 10 days (opinion).

Considering all of the factors above, a cycle time of 30 days was assumed for the analysis presented in Attachment 3, and calculated for each package separately for the analysis presented in Attachment 2.

\section{Package Size Limit:}

- Assume a maximum internal width of six feet for truck and eight feet for rail. This assumes slightly more than a foot for the package sides, and provides adequate structural integrity and double containment, with a truck width diameter of 8.5 feet and 10.5 feet for railcar. The TRUPACT-II has a six foot internal diameter

- Assume a package end or impact limiter structure of two feet on each end. The TRUPACT-II has about two feet of end structure

- Package height has been given as the same as width but there is flexibility for some increase for rectangular cross-section packages.

\section{Package Cost:}

- A cost is assumed for TRUPACT-II of $\$ 335,000$ for a reasonable quantity ordered. The current TRUPACT-II contract cost (solicitation DE-RP04-99AL79755) varies from $\$ 318,000$ to $\$ 545,000$ depending on whether it is an initial production, the quantity ordered, and whether it is a new or experienced manufacturer. The HalfPACK, a shorter version of the TRUPACT-II, contract cost varies from $\$ 314,000$ to $\$ 419,000$ as a follow-on to TRUPACT-II production. Longer or shorter versions, minor design changes, are not considered a significant cost factor.

- New packages that are minor perturbations to the TRUPACT-II have a cost for development and testing of $\$ 3$ million. New cylindrical packages are assumed to have a cost for development and testing of $\$ 6$ million. New rectangular packages will be more difficult to build and permit, with a production cost assumed to be twice that of a TRUPACT-II, with development and testing costs in the range of $\$ 15$ million.

- $\quad$ TRUPACT-II cost is $\$ 335,000$

- Cylindrical new package cost is approximately $\$ 500,000$

- Rectangular cross-section new package cost is approximately $\$ 750,000$

- New length extension TRUPACT-II development cost is estimated to be $\$ 3$ million

- $\quad$ Larger diameter cylindrical package development cost is estimated to be $\$ 6$ million

- New rectangular cross-section package development cost estimated to be $\$ 15$ million 


\section{Attachment 6 Defining Constraints}

\section{Railcar:}

- Railcar package size limits:

- Width: 7 feet 4 inches to 10 feet 8 inches. The team assumed 10.5 feet wide.

- Length: 54 feet to 89 feet 4 inches. The team assumed a 60 foot length for a standard car and 80 feet for an articulated flatbed railcar (section in middle designed to flex or pivot when going around curves)

- Height: 15 feet high from rail and 3 feet from rail to bed of "lowboy" rail car

- Maximum gross weight limit is 260,000 pounds per railcar

- Estimated net payload weight on a flatcar is 180,000 to 200,000 pounds

- As a reference, the ATMX railcar, which is an existing railcar not approved by the NRC for TRU waste shipments to WIPP, has the following dimensions:

- External dimensions: 10.0 feet wide, 59 feet 10 inches long, and 13 feet 10 inches high above the rail

- Internal dimensions: 9 feet 4 inches wide, 9 feet 2 inches high, and 50 feet long. It is designed to hold two waste packages loaded through the roof measuring 8 feet wide, 9 feet high, and 20 feet long. It requires about one day to load ( 8 hours)

- Payload of 144 55-gallon drums, with a weight of a unit at 118,700 pounds, which translates to a 101,300 pound payload. Previous experience indicates 144 drums were carried in each ATMX car, with the average drum weight at 703 pounds average.

\section{Truck:}

- Truck package size limits:

- Width: 8.5 feet

- Length: 45 feet maximum

- Height: 13.5 feet above roadbed. The team assumed 10 feet above the truck bed, which is the same as for a TRUPACT-II

- Maximum legal weight of truck, trailer, and load (GVW) is 80,000 pounds. This may increase to 90,000 pounds in the future

- Assume the truck and trailer weighs 28,000 pounds (TRUPACT-II system) with package and payload at 52,000 pounds. This calls for 14 drums per TRUPACT-II, 3 TRUPACT-II's per trailer, with each drum weighing 312 pounds average.

\section{WIPP:}

- Cage (elevator) dimensions: 9 feet wide, 15 feet high, 15 feet long

- Cage load 23 tons, or 46,000 pounds (rated at 45 tons maximum)

- The mine ceiling at its lowest height dimension is 13 feet

- Waste packages shipped to WIPP must be NRC approved. The NRC currently only approves Type B packages. The ATMX is an exempted Department of Transportation package, is not NRC approved, and is not currently approved for shipment to WIPP

- Operating life of WIPP is 35 years, or until FY 2033. 
Package contents: The following are typical of the waste packages found in the complex:

- Waste drum: 55-gallon drum, Type A, with external dimensions of 24.10 inch diameter and 35 inches high, and assume a four inch high pallet

- Standard Waste Box is a Type A package measuring 6x4.5x3 feet

- Drum Overpack: 85 gallon drum configured as a four-pack and fits in TRUPACT-II

- Ten-Drum Over Pack (TDOP) which fits in a TRUPACT-II

- Waste box size varies, but a common size is $4 \times 4 \times 7$ feet (See Table 1)

\section{Transportation:}

- Allowable transport time less than 30 days (60 day hydrogen gas generation limit with safety factor) 